Interrogating "Whiteness," Complicating "Blackness": Remapping American Culture Author(s): Shelley Fisher Fishkin

Source: American Quarterly, Vol. 47, No. 3 (Sep., 1995), pp. 428-466

Published by: The Johns Hopkins University Press

Stable URL: http://www.jstor.org/stable/2713296

Accessed: 09-06-2015 16:59 UTC

Your use of the JSTOR archive indicates your acceptance of the Terms \& Conditions of Use, available at http://www.jstor.org/page/ info/about/policies/terms.jsp

JSTOR is a not-for-profit service that helps scholars, researchers, and students discover, use, and build upon a wide range of content in a trusted digital archive. We use information technology and tools to increase productivity and facilitate new forms of scholarship. For more information about JSTOR, please contact support@jstor.org. 


\title{
Interrogating "Whiteness," Complicating "Blackness": Remapping American Culture
}

\author{
SHELLEY FISHER FISHKIN
}

University of Texas

This essay is dedicated to the memory of Ralph Ellison (1914-1994)

IN 1958, RALPH ELLISON GENTLY CHIDED WHITE AMERICANS FOR BEING "so absurdly self-deluded over the true interrelatedness of blackness and whiteness."1 It was a message neither white nor black Americans were ready to hear. So, for the next thirty years, they ignored it. When I interviewed Ellison in the summer of 1991, I sensed his frustration that his critical arguments had had so little impact on the cultural conversation. His excitement about my own work on the "interrelatedness of blackness and whiteness" meant the world to me, and his encouragement and support helped spur me on. In 1993, when my book Was Huck Black? Mark Twain and African-American Voices came out, I was aware of two or three books published that same year in the United States that tilled adjacent fields. I suspected that my work might be part of a growing trend. But how many isolated academic forays add up to a "trend?" Ten? Twenty? Thirty? In this essay I will provide a brief overview of over a hundred books and articles from fields including literary criticism, history, cultural studies, anthropology, popular culture, communication studies, music history, art history, dance history, humor studies, philosophy, linguistics, and folklore, all published between 1990 and 1995 or forthcoming shortly. Taken together, I believe, they mark the early 1990 s as a defining moment in the study of

Shelley Fisher Fishkin is a professor of American studies and English at the University of Texas, Austin. Her most recent book is Was Huck Black? Mark Twain and AfricanAmerican Voices (New York, 1993). An expanded version of this essay will appear in Criticism on the Color Line: Desegregating American Literary Studies, ed. Henry Wonham (New Brunswick, N.J., 1996).

American Quarterly, Vol. 47, No. 3 (September 1995) (C) 1995 American Studies Association 
American culture. For in the early 1990s, our ideas of "whiteness" were interrogated, our ideas of "blackness" were complicated, and the terrain we call "Americah culture" began to be remapped. ${ }^{2}$

\section{Interrogating "Whiteness"}

If you're white, you're all right.

If you're brown, stick around.

But if you're black, get back.

-African-American folk saying

To be white in America is to be very black. If you don't know how black you are, you don't know how American you are.

-Robert Farris Thompson, "The Kongo Atlantic Tradition"

Combatants in the canon wars of the 1980s argued that writing by African Americans had been previously unjustly excluded from the curriculum. New courses proliferated. But, as Dean Flower observed in the Hudson Review in 1994,

the definition of "American" literature did not change. In the college classroom American literature was, and still mainly is, defined by the socalled "classic" texts and "major figures"—as if black writers had really made no difference in our literary history until, say, Native Son. Look in any publisher's college catalogue. The canonized (white) writers, who represent "the American tradition," are listed in one place, the African Americans appear in another. Students take courses on "Afro-American" writers or "Black Studies," almost always taught by persons of color, and they take courses in American literature, almost always taught by white persons in departments of English. The segregation could not be more emphatic. ${ }^{3}$

A study published in January 1990 found that college courses with such titles as "The Modern Novel" or "Modern Poetry" continued to be dominated by "works almost exclusively by elite white men." ${ }^{\text {N }}$ Nonetheless, calling attention to the "whiteness" of the curriculum was still considered bizarre and provocative behavior. A professor who called the standard American literature survey she taught "White Male Writers" was held up to ridicule by Time magazine. ${ }^{5}$ Evidently the editors subscribed to the idea (as George Lipsitz puts it in his essay in this issue of American Quarterly) that "whiteness never has to speak its name, never has to acknowledge its role as an organizing principle in social and cultural 
relations." Time's behavior reflected the widely held assumptions that American culture is obviously white culture and that stating the obvious is superfluous, irritating, and perverse.

While the idea of the social construction of "blackness" was increasingly discussed in the 1980s, the idea of "whiteness" as a construct did not receive widespread attention until the 1990s. In the 1990s, scholars asked with increased frequency how the imaginative construction of "whiteness" had shaped American literature and American history. Some of our culture's most familiar (and canonical) texts and artifacts turned out to be less "white," on closer look, than we may have thought; the "whiteness" that had previously been largely invisible in the stories we told about who we were suddenly took center stage as the site where power and privilege converged and conspired to sabotage ideals of justice, equality, and democracy.

With the 1992 publication of her book Playing in the Dark: Whiteness and the Literary Imagination, Toni Morrison launched an eloquent and provocative challenge to the privileged, naturalized "whiteness" of American literature. Expanding on her earlier groundbreaking Michigan Quarterly article, Morrison rejected the assumption that "traditional, canonical American literature is free of, uninformed, and unshaped by the fourhundred-year-old presence of, first, Africans and then African Americans in the United States." She made explicit that which had been implicit in American literary study from the start. "There seems to be a more or less tacit agreement among literary scholars," Morrison wrote, that, because American literature has been clearly the preserve "of white male views, genius, and power, those views, genius and power are without relationship to and are removed from the overwhelming presence of black people in the United States. ..." "The contemplation of this black presence," Morrison argued, "is central to any understanding of our national literature and should not be permitted to hover at the margins of the literary imagination." Analyzing works by Poe, Hawthorne, Melville, Twain, Cather, and Hemingway, among others, Playing in the Dark challenged scholars to examine "whiteness" as an imaginative, social, and literary construction, to explore the ways in which "embedded assumptions of racial (not racist) language work in the literary enterprise that hopes and sometimes claims to be "humanistic." "6 Playing in the Dark put the construction of "whiteness" on the table to be investigated, analyzed, punctured; and probed. Morrison's book offered a set of questions and an agenda for research that 
resonated with a number of projects already under way (including my own) and that also helped spark myriad new publications.

The importance of this approach, however, was far from universally recognized. As Eric J. Sundquist observed in 1993 in To Wake the Nations: Race in the Making of American Literature, "it remains difficult for many readers to overcome their fundamental conception of 'American' literature as solely Anglo-European in inspiration and authorship, to which may then be added an appropriate number of valuable 'ethnic' or 'minority' texts." Morrison, Sundquist, and I were suggesting that these divisions failed to do justice to the complex roots of American culture.

This argument did not burst onto the scene full-blown in the 1990s. As I have noted, as early as 1958, Ralph Ellison had commented on the "interrelatedess of blackness and whiteness," and, in 1987, Toni Morrison laid important groundwork in "Unspeakable Things Unspoken." Sundquist helped prepare the way as well in the late 1980s with his own publications on Twain and Faulkner and the essay collection on Stowe that he edited. ${ }^{8}$ In a 1986 essay (in Sundquist's Stowe anthology) entitled "Sharing the Thunder: The Literary Exchanges of Harriet Beecher Stowe, Henry Bibb, and Frederick Douglass," Robert Stepto demonstrated the importance of investigating the African-American roots of canonical American fiction, a move that scholars would soon make with increasing frequency. ${ }^{9}$ Two other American critics pursued some preliminary explorations of this territory in the late 1980s as well. In his final chapter of The Unusable Past: Theory and the Study of American Literature (1986), for example, Russell Reising asked how the American Renaissance would look if we posited Frederick Douglass as central to it. In his imaginative juxtaposition of analyses of passages from Douglass and Thoreau, in which both writers explore "America's blindness to its own darker truths," Reising demonstrates affinities and intersections previously missing, for the most part, from discussions of either writer. Reising argues that

Douglass's life, his works, the institution of slavery, and the struggle against slavery waged by black and white alike are the material, social, and political basis on which the works of other major writers of the American Renaissance are founded. The dynamics of slavery made [their works] possible. ${ }^{10}$

Aldon Lynn Nielson's 1988 book, Reading Race: White American Poets and Racial Discourse in the Twentieth Century, was another early study that argued that ideas about race played an important role in shaping 
canonical American literature, and this vein was mined as well by several of the contributors to the 1989 volume, Slavery and the Literary Imagination, edited by Deborah E. McDowell and Arnold Rampersad. ${ }^{11}$ But if the 1980s brought a handful of essays and books, the early 1990s positively exploded with literary studies in this mode.

In the early 1990s, a number of critics in addition to myself took up Morrison's challenge to examine mainstream American "literature for the impact Afro-American presence has had on the structure of the work, the linguistic practice, and fictional enterprise in which it is engaged." ${ }^{12}$ Dana Nelson's The Word in Black and White: Reading "Race" in American Literature 1638-1867 (1992) examined the ways in which seventeenth-, eighteenth-, and early nineteenth-century "white" writers constructed versions of their own identity (and of American identity) by defining themselves as unlike various racial and ethnic "others"; Nelson offered fresh insight into familiar writers, such as Cotton Mather, James Fenimore Cooper, William Gilmore Simms, and Catharine Maria Sedgwick. ${ }^{13}$ Sterling Stuckey in Going through the Storm: The Influence of African American Art in History (1994), Eric Sundquist in To Wake the Nations (1993), and Viola Sachs in L'Imaginaire Melville (1992) have demonstrated Herman Melville's deep interest in African customs, myth, languages, and traditions and have pointed out the African influences on works such as Moby-Dick and "Benito Cereno." 14 (Sachs, for example, has uncovered numerous references to the Yoruba god Legba in Moby-Dick. Stuckey and Sundquist have examined the use of Ashanti drumming and treatment of the dead in "Benito Cereno," suggesting that the treatment of the corpse of the rich slaveholder Aranda in "Benito Cereno" was not a racist allusion to African savagery, as critics have argued, but rather, evidence of Melville's insight into Ashanti rituals and the shrewd political use his characters made of those traditions.) And in "Moby-Dick and American Slave Narrative" (1994), Michael Berthold argues for the centrality of African-American traditions to Melville's art. ${ }^{15}$ While my own work explored the ways in which African-American voices and oral traditions shaped Huckleberry Finn, the 1990s brought essays on Twain by Werner Sollors and Lawrence Howe that examined the influence of slave narratives on Connecticut Yankee and Life on the Mississippi. ${ }^{16}$ In Black and White Strangers: Race and American Literary Realism (1993), Kenneth W. Warren examines the way implicit assumptions about race illuminate the work of Henry James and William Dean Howells. 
Warren (like Nelson, Sundquist, Stuckey, and Sachs) argues for the importance of investigating "the mutually constitutive construction of 'black' and 'white' texts in American literature." "Concerns about 'race' may structure our American texts, even when those texts are not 'about' race in any substantive way," Warren maintains. "For James," Warren observes, "the art of fiction is always a reflection on the social conditions necessary for sustaining fiction as high art." Warren's book sheds new light on both the fiction of James and Howells and the society that shaped it and that it helped shape. Along the way, he generates some intriguing insights into turn-of-the-century culture-such as the "inadvertent alliance between Northern realism and Southern romance in an assault on the political idealism of the New England tradition."17

In recent studies of canonical white twentieth-century figures as well, unexpected links to African and African-American culture are being explored. While Robert Fleissner examines the influence of African myths on T. S. Eliot, David Chinitz demonstrates intriguing connections between Eliot's poetry and jazz. ${ }^{18}$ The construction of "whiteness" on the part of Eliot as well as other canonical white writers in the twentieth-century is examined by Michael North in The Dialect of Modernism: Race, Language and Twentieth-Century Literature (1994). North explores the role of "racial masquerade" and "linguistic imitation" in the works of modernists including Gertrude Stein, T. S. Eliot, Ezra Pound, and William Carlos Williams. ${ }^{19}$ The course of modernist writing in America, North demonstrates, was shaped indelibly by the linguistic racial impersonations in which these writers engaged. Probing, for example, Pound's and Eliot's excursions into what they thought of as black dialect (lifted from "the world of Uncle Remus"), North observes that "preemptive mimicry of blacks is a traditional American device allowing whites to rebel against English culture and simultaneously use it to solidify their domination at home." ${ }^{20}$ North also addresses the dynamics of William Carlos Williams's complicated attraction to African-American language and literature, as does Aldon L. Nielson, in Writing between the Lines: Race and Intertextuality (1994). ${ }^{21}$ In a series of articles culled from a longer work on the discourse of race in poetry, Rachel Blau DuPlessis examines some related issues not only in the work of Eliot, Pound, and Williams but also in the poetry of Vachel Lindsay, Wallace Stevens, Marianne Moore, Mina Loy, and Gertrude Stein. ${ }^{22}$

While Nielson, North, and DuPlessis explore the complex relationship 
that "white" modernist poets such as Pound, Eliot, and Williams had to race-inflected language, Laura Doyle's Bordering on the Body: The Race Mother in Modern Fiction (1994) explores the centrality for white modernist novelists on both sides of the Atlantic-including James Joyce, Virginia Woolf, and William Faulkner-of what Doyle refers to as the concept of the "race mother."23 Ideas of "racial patriarchy," according to Doyle, play a key role in shaping the cultural matrix of high modernism. As Carla Peterson's essay on Gertrude Stein in Criticism on the Color Line demonstrates, discussions of white modernists can be enriched by examinations of the role played by ideas of "blackness"- on both the linguistic and thematic levels-in the genesis of their work. ${ }^{24}$

The "whiteness" of several forms of popular culture, as well as high culture, was similarly interrogated in the early 1990s, as familiar artifacts generally understood as "white" were shown to have roots more complicated than previously recognized. Joe Adamson and David Roediger, for example, explored the African roots of Bugs Bunny. ${ }^{25}$ As Roediger puts it in a 1994 essay (building on Adamson's extended treatment of the subject in his 1990 book on Bugs Bunny),

Bugs' heritage is anything but white. The verb "bugs" [as in] "annoys" or "vexes," helps name the cartoon hero. Its roots, like those of "hip," lie partly in Wolof speech.

Moreover, the fantastic idea that a vulnerable and weak rabbit could be tough and tricky enough to menace those who menace him enters American culture, as the historian Franklin Rosemont observes, largely via Br'er Rabbit tales.

These stories were told among various ethnic groups in West Africa, and further developed by American slaves before being popularized and bastardized by white collectors like Joel Chandler Harris. They were available both as literature and folklore to the white Southerner Tex Avery whose genius so helped to give us Bugs. ${ }^{26}$

Howard L. Sacks and Judith Rose Sacks argue convincingly that a nineteenth-century black family in Ohio wrote "Dixie," the song that became known as the anthem of the Confederacy. Building their case from family records, public documents, and oral histories, the Sacks's Way up North in Dixie: A Black Family's Claim to the Confederate Anthem (1993) details the history of the Snowdens, a farming family who performed banjo and fiddle tunes and popular songs for black and white audiences throughout rural central Ohio from the 1850s through the turn-of-thecentury. The song's reputed white composer, Dan Emmett, heard the 
Snowdens sing the song and appropriated it as part of his minstrel show repertoire, bringing it to a wide and receptive public. ${ }^{27}$

The complex blend of appreciation and appropriation of black culture that the minstrel show represented is the subject of Eric Lott's Love and Theft: Blackface Minstrelsy and the American Working Class (1994), in which the role of the minstrel show in the construction of working-class white identity in nineteenth-century America receives the attention it has long deserved. Lott takes as his starting point the conventional view of the minstrel show:

while it was organized around the quite explicit "borrowing" of black cultural materials for white dissemination, a borrowing that ultimately depended on the material relations of slavery, the minstrel show obscured these relations by pretending that slavery was amusing, right, and natural.

But he continues, "I am not so sure that this is the end of the story." In addition to being all of the above, Lott explains, "blackface performance, the first public acknowledgment by whites of black culture," required "small but significant crimes against settled ideas of racial demarcation" that have been little noticed before. Lott's larger concern is "how precariously nineteenth-century white working people lived their whiteness." 28

Lott's stimulating study resonates with work in the field of history by David R. Roediger, whose important books The Wages of Whiteness: Race and the Making of the American Working Class (1991) and Towards the Abolition of Whiteness (1994) helped foreground "whiteness" on historians' agendas in the 1990s. ${ }^{29}$ As Roediger observes in the latter volume,

\footnotetext{
When residents of the US talk about race, they too often talk only about African Americans, Native Americans, Hispanic Americans, and Asian Americans. If whites come into the discussion, it is only because they have "attitudes" towards nonwhites. Whites are assumed not to "have race," though they might be racists.
}

But "the whiteness of white workers," Roediger demonstrates, "far from being natural and unchallengeable, is highly conflicted, burdensome, and even inhuman." Roediger offers these essays-which investigate the construction of "whiteness" at various points in American labor historyas "political, as well as historical, interventions" designed to explode, as he puts it, "the idea that it is desirable or unavoidable to be white." Roediger believes that "making whiteness, rather than simply white racism, the focus of study has had the effect of throwing into sharp relief the impact 
that the dominant racial identity in the US has had not only on the treatment of racial 'others' but also on the ways that whites think of themselves, of power, of pleasure, and of gender." 30

Both "whiteness" as a social and political construct in Roediger's terms, and the kind of complex cultural exchange to which Lott paid such close attention, figure in the work of scholars from the humanities and the social sciences in the early 1990s who, in a variety of ways, asked the question, "are Jews 'white'?" Sander Gilman observes, for example, in his 1991 book The Jew's Body, "For the eighteenth- and nineteenth-century scientist, 'the blackness' of the Jews" was assumed. ${ }^{31}$ Gilman notes that the author of an 1850 tract that became "one of the most widely cited and republished studies on race," for example, referred to "the African character of the Jew, his muzzle-shaped mouth and face." 32 Because of skin color and facial characteristics, Jews were "quite literally seen as black." In his final chapter, Gilman examines the genesis of the 1927 film "The Jazz Singer" and the image of Al Jolson, playing a cantor's son, at the film's close "on bended knee, [singing] 'Mammy' in black-face for his hugely successful Broadway opening." Gilman refers to "the long vaudeville tradition of white performers putting on black-face" and then returns to his original question:

Are Jews white? Or do they become white when they . . . acculturate into American society, so identifying with the ideals of "American" life, with all its evocation of race, that they - at least in their own mind's eye-become white? Does black-face make everyone who puts it on white? ${ }^{33}$

In his 1992 article, "Blackface, White Noise: The Jewish Jazz Singer Finds His Voice," Michael Rogin further explores the complex matrix involving whiteness, blackness, and Jewishness in "The Jazz Singer," a film which, Rogin observes, "appropriated an imaginary blackness to Americanize the immigrant son." 34 And in her innovative 1994 essay entitled "How Did Jews Become White Folks?" anthropologist Karen Brodkin Sacks explores the economic, social, and psychological impact of post-World War II changes in real estate practices on Jewish and black Americans. ${ }^{35}$

Historians' interrogation of "whiteness" in the early 1990s primarily took one of two forms: 1) explorations of the dynamics of the construction of "white" identity along the lines suggested by Roediger (Alexander Saxton's The Rise and Fall of the White Republic: Class Politics and Mass Culture in Nineteenth-Century America [1990] is a key work in this vein) $; 36$ and 2) investigations of African-American roots of mainstream 
(and supposedly "white") American culture. Studies in this second category built on the earlier extremely valuable work of Melville Herskovits and Peter Wood as well as on the broad-ranging investigations of Sidney Kaplan. ${ }^{37}$ Herskovits, some fifty years ago, had argued in The Myth of the Negro Past that the brutality of the Atlantic slave trade and the oppressions of American bondage did not destroy the African cultural heritage; aspects of African culture (such as language use), Herskovits argued, both survived in the African American community in the twentieth-century, and influenced aspects of mainstream culture as well. Twenty years ago, in Black Majority: Negroes in Colonial South Carolina from 1670 through the Stono Rebellion, Wood demonstrated the large number of African contributions to colonial American agriculture, animal husbandry, and other fields-including rice cultivation, cattle breeding, open grazing, basketry, medicinal practices, and, in certain regions (particularly South Carolina), boat building, fishing, hunting, and trapping-while Kaplan (in several books and more than fifty articles written over the last forty years) explored the African-American presence in whaling, shoe manufacturing, classical American painting, and military history. In the 1990s, this line of research has been pursued by at least two historians and a folklorist: John Edward Philips, in his essay "The African Heritage of White America" in Africanisms in American Culture edited by Joseph E. Holloway (1990); William D. Piersen in Black Legacy: America's Hidden Heritage (1993); and Roger Abrahams in Singing the Master: The Emergence of AfricanAmerican Culture in the Plantation South (1992). ${ }^{38}$

Philips's essay provides a helpful summary of work on the subject prior to 1990 and a useful agenda for future research. Philips makes explicit some of the implications for white culture of research on African retentions in African-American culture undertaken by scholars in the 1970s and 1980s. Scholars who set out to investigate African influences on AfricanAmerican culture, Philips notes, may have been less successful in their efforts "to document much that is specifically African about the way black culture in the United States differs today from white culture" than they have been at showing "how African influences are one important way in which American culture differs from European." While he is fully aware of the complex and problematical challenges entailed in researching the subject, Philips believes that "when social scientists and historians begin to investigate systematically the survival of African culture among EuropeanAmericans they will discover that as much African culture survives now among whites as among blacks in the United States." "For too long in this 
country," Philips notes, "whites have denied learning from blacks"; in addition, some blacks themselves have often been reluctant to acknowledge any links to Africa. ${ }^{39}$ In 1969, in his essay "Clio with Soul," C. Vann Woodward had observed, "so far as their culture is concerned, all Americans are part Negro." ${ }^{40}$ But, as Philips notes, rather than providing an agenda for historians, the comment passed largely unnoticed.

Philips gives a sample of the kinds of interesting links that scholars might pursue in the future, exploring, for example, potential connections between African singing and instrumental styles and bluegrass music. While his method is of necessity conjectural, some of the fruits of it are intriguing, as his discussion of the potentially African roots of Jimmie Rodgers's "yodeling" demonstrates. Philips also urges scholars to probe "white Africanisms" in the fields of religious belief (particularly in Pentecostal churches), traditions of Southern hospitality and courtesy, Southern foodways and cooking techniques, cowboys' cattle-herding techniques and migratory patterns, and language use. Arguing that "pride in their African heritage is something that white children should be taught along with blacks," Philips presses for "a more complex paradigm to explain African cultural retentions than has hitherto been advanced," one that recognizes the constant process of cultural exchange that has continued throughout American history. Philips concludes:

African culture among whites should not be treated as just an addendum to studies of blacks but must be included in the general curriculum of American studies. Black studies must not be allowed to remain segregated from American studies but must be integrated into our understanding of American society, for our understanding of white American society is incomplete without an understanding of the black, and African, impact on white America. ${ }^{41}$

Historian William D. Piersen's Black Legacy: America's Hidden Heritage (1993) takes up this challenge, assembling an impressive compendium of ways in which African culture shaped white American culture, particularly in the South. Culling intriguing examples from a vast range of primary sources to make his case, Piersen explores cultural phenomena including storytelling, language use, music, manners, etiquette, folk medicine, folk beliefs, cooking styles, and communal celebrations. Ambitious and boldly synthetic, Black Legacy succeeds in persuading the reader that "the legacy of African culture is important to the understanding of America." 42 
Pierson documents a range of medical innovations for which slave medical practitioners were responsible, including being the first to use inoculation as a method of reducing the seriousness of smallpox epidemics and increasing the American pharmacopoeia stock with the addition of at least seventeen African herbal drugs. Drawing on Gwendolyn Midlo Hall's book Africans in Colonial Louisiana (1992), ${ }^{43}$ he notes that slave practitioners regularly cured scurvy with lemon juice thirteen years before European physicians advocated a similar cure. Piersen also examines briefly the interpenetration of black and white speech patterns and musical traditions.

In the book's strongest chapter ("A Resistance Too Civilized to Notice"), Piersen tracks the use of satiric traditions from Africa to the new world, pulling together a dazzling set of specific examples. He provides an overview of the use of satirical songs (sometimes called "songs of derision" by other scholars) as a mechanism of social control in eighteenth- and nineteenth-century African societies, noting the ways in which they allowed the weak to voice grievances against the strong with impunity. Piersen explores the ways in which satirical songs functioned in colonial African cultures and then moves to their manifestations in the antebellum American South. (Piersen's explorations of this subject in an earlier article provided important background to my work on the AfricanAmerican roots of Mark Twain's satirical treatment of racism.)

Roger Abrahams also explores the development of satirical performance rituals in Singing the Master: The Emergence of African-American Culture in the Plantation South (1992). As Abrahams observes, we have yet to "describe effectively the dynamic, expressive interrelations of [black and white] cultures living side by side" in antebellum America. ${ }^{44}$ His detailed study of corn-shucking rituals provides a model of how such interactions might be probed by scholars in the future. Underlying Abrahams's study is his agreement with W. J. Cash's famous comment that "Negro entered into white man as profoundly as white man entered into Negro-subtlely influencing every gesture, every word, every emotion and idea, every attitude." 45 Building on work by John Szwed and others, Abrahams suggests, for example, that while the American square dance grew out of European dances such as the reel and the quadrille, the distinctly American practice of calling square-dance figures in rhyme has its roots in cornshucking customs in the South, where in the plantation yard teams of slaves entertained themselves and their masters with improvised rhymes as they husked corn. A great deal of the culture of the South, Abrahams 
argued, took shape not in the slave quarters or the Big House, but "in the yard between" the two, "in contested areas betwixt and between the two worlds." 46

Abrahams's careful reexamination of the intercultural dynamics of slave holidays in the antebellum South, combined with Lott's reconsideration of the role of minstrelsy in the antebellum North, lays the groundwork for new understandings of much of mainstream American culture from the early nineteenth century to the present. The traces left by slave holidays on American life, Abrahams observes, were far-reaching. The Beatles, he notes, "began their career as an English skiffle band" indebted to traditions of "the black skiffle and jug bands of the early twentieth century" which "were descendants of minstrel music. And the mountain string band emerged from the blackface stage, and in its wake, the bluegrass band: making them white imitations of a blackface imitation of a plantation musical group." 47

Some of the ironies and intricacies of this process of imitation and exchange are probed by David Roediger in his illuminating article, "Guineas, Wiggers, and the Dramas of Racialized Culture." ${ }^{8}$ Roediger frames his discussion with the question Ralph Ellison asked two decades ago: "What, by the way, is one to make of a white youngster who, with a transistor radio, screaming a Stevie Wonder tune, glued to his ear, shouts racial epithets at black youngsters trying to swim at a public beach ... ?"

The "Ellison question" humanizes key contradictions in white consciousness in the late twentieth century. We might wish to update the images: racist skinheads dancing to ska music; bluesman and Willie Horton advertisement promoter Lee Atwater; the white kid with an $\mathrm{X}$ hat and a rebel flag belt buckle; the precise coincidence of a national outpouring of love and sympathy for Magic Johnson with majority white support for David Duke in Louisiana elections.

What, Roediger asks, can be "made of the impulses which at once and often in the same person lead to tremendous attraction toward 'nonwhite' cultures and toward hideous reassertions of whiteness as what the theorist and activist A. Sivanandan has called a "political color?" "49 The "tragic and dramatic complexities of the Ellison Question," Roediger notes, come to the fore when one examines the relatively recent coinage "wiggers," meaning "white niggers" or "whites acting 'too black."” Roediger tracks recent use of this term as "a slur against whites by whites" in Detroit, Michigan; Madison, Wisconsin; Warren, Ohio; Buffalo, New York; and, 
most dramatically, in Morocco, Indiana, where the hiphop fashions and musical tastes of some young, rural white women recently resulted in their being called "wiggers," suspended from school, spat upon, and threatened with death by white male students who demanded that they "dress white." The term has also been used affectionately by African Americans to "name whites seriously embracing African-American cultural forms and values, in contrast to 'wannabe' dabblers in the externalities of rap. . .."51 "The dynamics of cultural hybridity," Roediger notes, "have long featured much that is deeply problematic on the white side." 52 While Roediger makes clear the difficulty of determining the ultimate social consequences of contemporary white youth's attraction to African-American popular culture, his discussion of white hiphop consumers makes the point that "to an unprecedented extent white youth are listening to an explicit critique, often an unsparing critique, of 'white' society." 53

Like Piersen, Philips, and Abrahams, Roediger takes pains to trace the African roots of cultural phenomena recognized throughout the world as "modern U.S. culture." ${ }^{4}$ When they identify with hiphop, Roediger writes, white rap fans are drawing unconsciously on an African heritage:

The hip in hiphop, and in so much else in modern U. S. culture, was put there by Africans. As the extraordinary research of David Dalby and others has shown, enslaved Wolof speakers, from what is now Senegal, probably carried "hipi" meaning "to open ones eyes, to be aware of what is going on" to the New World, as early as the late 1600s. In the melting pot of African ethnicities which slavery and black creativity melded into African American culture, "hip" survived and prospered.

Nearly three centuries later, it was still there, for whites to discover from jazz musicians. Even the beatnik ideal of the "hepcat" echoed the Wolof hipikat, meaning "someone with eyes open." The millions of white 1960s Americans who searched out eye-opening experiences as "hippies" adopted that name because they grew up in a culture permeated with African influences, although they didn't know it. ${ }^{55}$

While Roediger explores the African roots of "modern U.S. culture," scholars such as Josef Jarab and Renee Kemp-Rotan examine the AfricanAmerican roots of what is known in the United States as "modern European culture"- phenomena including Czech poetry and French architecture. A major strand of twentieth-century Czech poetry, Jarab maintains, grew out of Czech responses to blues and jazz recordings by African Americans. ${ }^{56}$ And Renee Kemp-Rotan has explored the influence of Josephine Baker on European architecture, planning, interior design, 
fashion, sculpture, graphic arts, painting, and photography. ${ }^{57}$ Paul Gilroy's felicitous "image of ships in motion across the spaces between Europe, America, Africa, and the Caribbean as a central organizing symbol" for his important book, The Black Atlantic: Modernity and Double Conscious$n e s s,{ }^{58}$ suggests the con-tinuous process of movement and cultural exchange that scholars are coming to understand as central not only to modern American culture but to modern European culture as well. The roots of modern Czech poetry and of Le Corbusier's architectural plans turn out to be, like Huck Finn and the song "Dixie," less "white" than we thought they were.

"Whiteness" was interrogated in the early 1990s in fields as diverse as humor studies, linguistics, art history, material culture, rhetoric and communications, and dance.

The impact of African-American humor upon mainstream "white" American sensibilities is explored by Mel Watkins in On the Real Side: Laughing, Lying and Signifying-the Underground Tradition of AfricanAmerican Humor that Transformed American Culture from Slavery to Richard Pryor (1994). ${ }^{59}$ Watkins, for example, notes that many popular jokes and stage routines of white comics in the 1940s and 1950s were pirated from black performers. He also offers a lucid and insightful analysis of the role black expressive culture played in shaping the fifties satire of Lennie Bruce (and, by extension, the subsequent forms of satire that developed out of it, including, as Watkins notes, the comedy of Saturday Night Live). Bruce's

comic assault on the intrinsic absurdity of race relations, religious practices, police tyranny, and hypocrisy concerning sex and drugs cut to the core of America's social contradictions. Moreover, he delivered his satirical thrusts in a hip, impious style that was clearly removed from polite middle-class society. Mirroring the street wit of the black musicians and night people with whom he associated, it smacked of a profane contempt that was both alien and frightening to mainstream America. ...

Bruce adopted aspects of the style and language of black hipsters and musicians. . . . He adopted the swagger and assertive impiety of the black Hipster in many of his routines and, more than any previous comedian on the mainstream stage, he evoked an iconoclasm and irreverence that mirrored the tempo and thrust of black street humor. ${ }^{60}$

Watkins's description of the African-American roots of Bruce's twentiethcentury satire resonate with my own research into the African-American roots of Mark Twain's nineteenth-century satire: clearly, African-American 
traditions of irreverent, satirical social criticism have been leaving indelible marks on American humor for the last two hundred years.

African-American elements in "white" speech and language use were increasingly probed in the 1990s in the fields of linguistics and communications. J. L. Dillard's chapter "The Development of Southern" in his 1992 book, A History of American English, is a case in point. Expanding on his earlier influential study of "black English," here Dillard collates additional lively and compelling evidence from primary and secondary sources that affirm the ways in which African Americans influenced what has come to be thought of as Southern speech. Dillard summarizes linguists' research, for example, on the potential "Black influence" in the formation of you all (y'all), the most frequently cited indicator of Southern dialect. He also makes the case for our conceiving "provisionally of a Black Englishinfluenced 'early Southern, from approximately 1750-1830."61 Although this book scales down some of the claims that made Dillard's earlier work so dramatic and controversial, its erudition and judicious tone amplify and solidify his arguments.

Other work in linguistics that charted adjacent territory includes The African Heritage of American English by Joseph E. Holloway and Winifred K. Vass (1993) and Language Variation in North American English, edited by A. Wayne Glowka and Donald M. Lance (1993). Holloway and Vass's long list of "Africanisms in Contemporary American English" and their derivations includes bad-mouth, banana, banjo, "be with it," bogus, booboo, bronco, bug (as in to annoy, offend), coffee, cola, cool, "do one's thing," guff, gumbo, guy, honkie, hulla-balloo, jam (as in music), jazz, jiffy, jive, kooky, okay, okra, phony, rap, ruckus, tote, uh-huh, mhm, uuh-uh, yam, yackety-yak, and you-all. ${ }^{62}$ The jambalaya (another Africanism) that Holloway and Vass serve up includes such tasty tidbits as "bambi: Bantu mumbambi, one who lies down in order to hide; position of antelope fawn for concealment (cf. Walt Disney, Bambi)." ${ }^{63}$

Like many of the books discussed in this essay, Language Variation in North American English: Research and Teaching, published by the Modern Language Association in 1993, was the fruit of initiatives in the scholarship and teaching of dialect that were launched throughout the preceding decade (as well as earlier). This volume is very much a 1990s artifact, however, in its readiness to foreground the way linguists' increasingly sophisticated awareness of how black contributions to "white" American speech changed the field of linguistics itself and what transpires in linguistics classrooms. Harold B. Allen, in "American English Enters 
Academe," describes some of his early efforts to get students to recognize the "various linguistic and cultural influences"-including what became known as "Black vernacular English"- that helped make American English "a variety of English distinct from British English." ${ }^{64}$ Walt Wolfram observes in his essay "Teaching the Grammar of Vernacular English" that "many of the students who previously abhorred the study of grammar have found genuine enthusiasm for examining the structures of vernacular dialects. In a real sense, studying the patterns of vernacular dialects has opened up a new life for the study of grammar." ${ }^{5}$

In the field of speech communication as well, "whiteness" and "white" American identity were foregrounded in the 1990s. Kathleen Hall Jamieson, for example, in Dirty Politics: Deception, Distraction, and Democracy (1992), masterfully examined the veiled racist verbal cues and visual subtexts designed to affect white voters' identification with particular candidates in political campaigns in the 1980s. ${ }^{66}$ Celeste Michelle Condit and John Louis Lucaites, in Crafting Equality: America's Anglo-African Word (1993), explored the ways in which the word "equality," an important "rhetorical foundation of the American national identity," drew its meaning, from the 1760 s to the present, from the interplay of black and white constructions of the term. ${ }^{67}$

The 1990s also brought new awareness of African-American influences on mainstream "white" American material culture, fine arts, and classical dance, as well as an examination of the idea of "whiteness" itself in the arts. In Models in the Mind: African Prototypes in American Patchwork (1992), Eli Leon argued that African motifs, organizational principles, and aesthetic values may well have shaped traditions of patchwork quilting in America that we have previously discussed solely in terms of their white antecedents. ${ }^{68}$ The decade opened with the publication of two seminal volumes exploring the role of African Americans in shaping mainstream "white" American painting-Guy C. McElroy's Facing History: The Black Image in American Art, 1710-1940 (1990), and Albert Boime's The Art of Exclusion: Representing Blacks in the Nineteenth Century (1990)-and with the republication (in 1991) of the introduction to Sidney Kaplan's pioneering 1964 exhibition catalog, The Portrayal of the Negro in American Painting. ${ }^{69}$ All of these discussions examined African-American images in the work of canonical and popular (primarily) white American artists, a field that was enriched and expanded by the 1992 publication in this country of Jan Nederveen Pieterse's White on Black: Images of Africa and Blacks in Western Popular Culture. ${ }^{70}$ In 1992, the concept of "white- 
ness" was interrogated in innovative ways by contemporary New York artists Kara Lynch, William Easton, Curlee Holton, Johan Grimonprez and Ayisha Abraham in a show curated by Todd Ayoung entitled "The Perverse Double: Or, a Cure for the Discourse of Whiteness."71 The early 1990s also brought Brenda Dixon-Gottschild's explorations of the role of African dance in shaping George Balanchine's American classical ballet. ${ }^{72}$

The move to recover and value the black influences on so-called "white American culture" was paralleled by a move to foreground the nature of white privilege and racism in American society. The early 1990s brought stimulating new work on this subject by scholars including Theodore Allen, Neil Foley, Jane Marcus, Vron Ware, Ruth Frankenberg, and bell hooks.

In The Invention of the White Race, vol. 1 (1994), Theodore W. Allen addresses the process by which the Irish "became white" in the United States and became enlisted as intermediaries in and supporters of the dominant culture's system of racial oppression and class privilege. ${ }^{73}$ Neil Foley, in a study of the racial politics of the socialist organizers in central Texas in the early twentieth century, explores a chapter of Texas history in which Mexican-Americans found themselves constructed by Anglos as "almost white.""

The early 1990s also brought several examinations of "whiteness" in a particularly gendered context, including two studies of the ways in which a series of upper-class and middle-class English women in the late nineteenth- and early twentieth-centuries deconstructed and reshaped their sense of "whiteness" as a result of their contact with African Americans. Jane Marcus's engaging article, "Bonding and Bondage: Nancy Cunard and the Making of the Negro Anthology," raises provocative questions:

What does it mean when Nancy Cunard switches roles and performs "the white woman being lynched" when in reality black men were being lynched in the name of revenge for white woman's lost honor? Can the figure of the "white woman hanged, bound, manacled, enslaved," ever disrupt in performance the racial fears of sexual mixing she wants to explode? Or is she unaware of the act she is putting on? . . . Can she enact the erotics of the white slave along with the politics of the protest against racism? ${ }^{75}$

And Vron Ware, in Beyond the Pale: White Women, Racism and History explores the role that Ida B. Wells and her attention to racial violence in turn-of-the-century America played in English reformers' constructions of their own identities as white women. ${ }^{76}$ 
The cognitive and emotional dimensions of American women's constructions of "whiteness" is the subject of Ruth Frankenberg's "Whiteness and Americanness: Explaining the Constructions of Race, Culture and Nation in White Women's Life Narratives" (1994) and of her White Women, Race Matters: The Social Construction of Whiteness (1993). ${ }^{77}$ Frankenberg believes that

the tasks of redefining and rehistoricizing "whiteness" are . . . vital concomitants of politicocultural struggles around race, from curriculum and canon transformation to the defense and extension of civil rights and racial equality. In other words, I would argue that critical engagements with the racial order must deconstruct and rearticulate whiteness at the same time as recentering the "others" upon whose existence the notion of whiteness depends.

Probing "the complex formation of white women's constructions of racialized selves," Frankenberg tries to "[rehistoricize] the categories of race and culture insisting on antiessentialist conceptions of race, ethnicity, and culture, while at the same time emphasizing that these categories are made materially 'real' within matrices of power relations." ${ }^{78}$ As bell hooks notes in Black Looks: Race and Representation (1992),

whether they are able to enact it as a lived practice or not, many white folks active in anti-racist struggle today are able to acknowledge that all whites (as well as everyone else within white supremacist culture) have learned to overvalue "whiteness" even as they simultaneously learn to devalue blackness. They understand the need, at least intellectually, to alter their thinking. Central to this process of unlearning white supremacist attitudes and values is the destruction of the category of "whiteness." 79

This goal is articulated with particular forthrightness in the inaugural 1993 issue of the Cambridge-based journal Race Traitor :

The white race is a club, which enrolls certain people at birth, without their consent, and brings them up according to its rules. For the most part the members go through life accepting the benefits of membership without thinking about the costs. . . Race Traitor seeks to dissolve the club, to break it apart, to explode it. ${ }^{80}$

The journal takes as its motto, "Treason to whiteness is loyalty to humanity." 


\section{Complicating "Blackness"}

I sit with Shakespeare and he winces not. Across the color line I move arm in arm with Balzac and Dumas ... I summon Aristotle and Aurelius and with what soul I will, and they come. ...

-W. E. B. Du Bois, The Souls of Black Folk

It wasn't unusual to be called "oreo" and "nigger" on the same day.

-Trey Ellis, "The New Black Aesthetic"

If the "whiteness" of mainstream American culture was axiomatic in the decades preceding the 1990s, the "blackness" of African-American culture was axiomatic as well. Courses and programs in "black studies" or "AfroAmerican studies" during this period played a crucial role in exposing a generation of students and future teachers to writers and texts previously excluded from the curriculum. Since "American" literature was defined, for the most part, as "white" literature, black writers were often taught in black studies courses or not at all. ${ }^{81}$ In these black studies courses, white writers and the literary conventions they employed were not considered crucial to the discussion; neither were white philosophical or spiritual traditions. (The white side of the family of "black" writers who were the children of interracial unions was generally an embarrassment and was ignored as much as possible.)

The essentialist paradigms that accompanied the move to recover and value black writers and black texts in the 1970s and 1980s began to give way in the early 1990s to a more complex view of African-American culture. ${ }^{82}$ Scholars increasingly analyzed the interpenetration of "black" and "white" culture in African-American letters and life. They examined more carefully the "white" roots of "black" American culture and gave more careful scrutiny to the "black" roots of African-American culture as well, replacing a vague homogenized idea of "Africa" with a sensitivity to specific African cultures and peoples.

As Henry Louis Gates, Jr., observed in 1984,

in the case of the writer of African descent, his or her texts occupy spaces in at least two traditions: a European or American literary tradition, and one of the several related but distinct black traditions. The "heritage" of each black text written in a Western language is, then, a double heritage, two-toned, as it were. Its visual tones are white and black, and its aural tones are standard and vernacular. ${ }^{83}$ 
Gates was relatively isolated in this position when he first voiced it. When his fellow scholars referred to "white" influences on "black" culture, they usually did so to condemn them. The 1990s, however, brought a new willingness to acknowledge and understand the interplay of traditions and voices that made African-American letters what they were. Often this involved re-evaluating the role that so-called "white" elements played in shaping "black" culture, as well as attending to dimensions of black culture previously ignored.

The historically Jim Crow nature of the curriculum had helped prompt scholars and teachers of black studies to emphasize the texts, writers, and chapters of history that struck them as being the "most black" and the "least white." Understandably, certain categories of people and certain forms of writing were privileged as implicitly more authentic and therefore more worthy of study. In antebellum America, it was the slave and slave narratives. In the early twentieth century, it was southern, rural, workingclass, vernacular speaking "folk" and fiction written about them (such as Zora Neale Hurston's Their Eyes Were Watching God); or it was blues singers and the blues. (I might add that Franklin Frazier's devastating and depressing critique of black middle-class life in 1957 in Black Bourgeoisie may well have reinforced an already-in-place tendency on the part of scholars to avoid attending to black middle-class experience.) Scholars of African-American culture in the early 1990s are increasingly asking, both directly and by implication, whether practices such as those I just described promoted a brand of essentialism that had the effect of redlining as subjects worthy of study writers, texts, ideas, and communities that failed to fit the mold.

Ann DuCille, for example, in The Coupling Convention: Sex, Text and Black Women's Fiction, observes that black women writers missed out on being in the earliest canon of American women writers because of their alleged preoccupation with race and were excluded from the earliest canon of African-American writers because of their alleged preoccupation with gender. By the time scholars were ready to construct a canon of AfricanAmerican women writers, many of the women and texts in DuCille's study lost out a third time around because of the class of their protagonists (middle), their language (standard English, not earthy vernacular), their skin color (light or white), and, as DuCille put it, the "so-called white" values, subjects, plots, and conventions (involving domesticity, marriage, and courtship) that were central to their fiction ${ }^{84}$ (It is also interesting that novels by black writers that feature only white characters-books that 
have long been largely ignored by critics-are now receiving attention. DuCille's extended discussion of Zora Neale Hurston's novel Seraph on the Suwanee in The Coupling Convention comes to mind, for example, as does the 1994 republication of Richard Wright's 1954 novel Savage Holiday, with an introduction by Gerald Early. ${ }^{85}$ )

In the 1990s, the validation of the "folk" as the only "authentic" African Americans gave way to interest in middle-class black people and communities throughout history. Works in this vein include, in addition to DuCille's book, impressive literary studies such as Carla Peterson's Doers of the Word: African-American Women Writers and Speakers in the North, 1830-1880; Claudia Tate's Domestic Allegories of Political Desire; Frances Foster's Written by Herself; and biographies of Nella Larsen, Frances Harper, and Archibald Grimké by Thadious Davis, Melba Boyd, and Dickson Bruce, all of which were published within the last three years. ${ }^{86}$ From historians, we have Adelaide Cromwell's 1994 book, The Other Brahmins: Boston's Black Upper Class, 1750-1950 and Willard B. Gatewood's 1990 book Aristocrats of Color: The Black Elite, 1880-1920, among others, as well as numerous recent studies of middle-class black professionals, including a history of black lawyers and studies of black men who work for IBM, of black women in academia, of black corporate executives, and of the challenges of black middle-class family life. ${ }^{87}$

Trey Ellis, in a stimulating and controversial essay in Callaloo entitled "The New Black Aesthetic," explores the middle-class backgrounds of many of the most prominent black rappers, artists whose cultivation of underclass personae mask their own decidedly nonunderclass roots. ${ }^{88}$

One categorical mistake many make is thinking that rap is only created by the hard-core children of the slums; that the black middle-class is too busy buying Polo shirts and branding their arms with fraternity emblems to care about black street culture and politics. In fact, most of the big-name rappers are middle-class black kids. . . . They make you realize that you don't have to be black and poor to be black and angry. ${ }^{89}$

(This sentiment is supported by many of the black executives whose comments Ellis Cose recorded in his 1993 book, The Rage of a Privileged Class.) "We no longer need to deny or suppress any part of our complicated and sometimes contradictory cultural baggage to please either white people or black,"-Trey Ellis asserts. "The culturally mulatto Cosby girls are equally as black as a black teenage welfare mother. Neither side of the tracks should forget that." ${ }^{.90}$ 
The paradigm that made the "slave narrative" the most truly "authentic" document of antebellum black America was challenged in the early 1990s not only by the important work of scholars including Carla Peterson and Frances Foster but also by the republication in 1993 (with a new introduction by William Andrews) of the diary of William Johnson, a free black in antebellum Natchez who became a successful businessman and by books such as Adele Logan Alexander's 1991 Ambiguous Lives: Free Women of Color in Rural Georgia, 1789-1879. ${ }^{91}$ James O. Horton in Free People of Color: Inside the African American Community (1993) urged scholars to address "the complexity of black life" by paying greater attention to diversity within the black community than was paid in the past. ${ }^{92}$ To this end, Horton addressed at length debates within the black community over how to negotiate the multiple identities imposed by gender, color, and nationality and how blacks and various immigrant groups in northern cities constructed each other and their world.

Our understanding of diversity within African-American culture was enriched as well in the 1990s by research on Afro-Dutch communities in New York and New Jersey in the seventeenth, eighteenth, and nineteenth centuries and by the publication of autobiographical and analytical narratives of African-American Jews. ${ }^{93}$

The 1990s brought a new willingness to acknowledge and understand the interplay of intellectual traditions and voices that made AfricanAmerican letters what they are. Often this involved re-evaluating the role that so-called "white" elements played in shaping "black" culture. For example, Michel Fabre's 1990 study, Richard Wright: Books and Writers, a fascinating examination of Richard Wright's reading, documented Wright's response to a wide range of white writers from the United States and abroad, including Dostoevsky, Theodore Dreiser, and Mark Twain. ${ }^{94}$ Interviews I conducted in the early 1990s tracked Mark Twain's influence on black writers including Ralph Ellison, Toni Morrison, and David Bradley ${ }^{95}$ The influence of Herman Melville on Bradley's own fiction and on fiction by other contemporary black writers is the subject of David Bradley's essay "Our Crowd, Their Crowd, and Moby-Dick."96 David Levering Lewis, in his magisterial biography of W. E. B. Du Bois, added depth and texture to our understanding of the influence of such figures as William James, George Santayana, Josiah Royce, and Nathaniel Shaler on Du Bois's intellectual development. ${ }^{97}$ Richard Yarborough 'demonstrated that Uncle Tom's Cabin influenced fiction by African Americans. ${ }^{98}$ Ann DuCille suggested that William Wells Brown's novel Clotel "talked back" 
to the sentimental fiction of Catharine Maria Sedgwick and Lydia Maria Child. ${ }^{99}$ And in work published in the last two years, Philip Richards and Carla Peterson join DuCille in arguing that traditions of white evangelical writing are crucial to understanding the work of black writers Phillis Wheatley, Frances Harper, Emma Dunham Kelley, Amelia Johnson, and others. ${ }^{100}$

"In some cases, the cross-race influence is direct and easily traced," Ann Douglas observes in Terrible Honesty: Mongrel Manhattan in the 1920s. After commenting that "the perfectly scanned and passionate poems of Countee Cullen sometimes read like companion pieces to the metaphorical, emotion-drenched, highly crafted poetry of Edna St. Vincent Millay," Douglas notes that "Cullen wrote his master's thesis at New York University on Millay and attended her poetry readings; Millay shared with him a lifelong commitment to the Romantic poets, who had been banished from favor by the white male literary elite."101

Michael Eric Dyson reminds us that "Ellison owed the habit of a critical style of reading, and the title of his first book of essays, to T. S. Eliot."102 Dyson, a dynamic critic of contemporary African-American culture, tracks his own sensitivity to the nuances of language, literature, and learning to a neighbor's unexpected gift of the Harvard Classics when Dyson was in his early teens, making him "the only boy on my block, and undoubtedly in my entire ghetto neighborhood, who simultaneously devoured Motown's music and Dana's Two Years before the Mast." ${ }^{103}$ As Dyson comments in his book Reflecting Black (1993),

As mature African-American scholars, teachers, students and citizens, we must embrace the rich and varied racial past that has contributed to our making. We must also acknowledge the profound degree to which we have alternately enjoyed and endured a terrible but sometimes fruitful symbiosis with European-American culture, how we have helped shape many of its cultural gifts to the world, even against its will, and how those expressions emerged in the crucible and turmoil of our uniquely African-American experience. ${ }^{104}$

If white literary and spiritual foremothers and forefathers of black writers received more attention from scholars, actual white ancestors and the often complicated responses they evoked from offspring defined as "black" by the pervasive "one-drop rule" received more attention as well. Adrian Piper, for example, in her incisive and creative 1992 essay, "Passing for White, Passing for Black," foregrounds the complexities of owning a dual heritage, as does Maureen T. Reddy in Crossing the Color 
Line: Race, Parenting and Culture (1994), Lise Funderburg in Black, White, Other: Biracial Americans Talk about Race and Identity (1994), Naomi Zack in Race and Mixed Race (1994), Shirlee Taylor Haizlipp in The Sweeter the Juice (1994), and many of the contributors to Gerald Early's stimulating 1993 anthology, Lure and Loathing: Essays on Race, Identity, and the Ambivalence of Assimilation. ${ }^{105}$ A related issue-the ironies, absurdities, and unreal realities of the racial classification system of the United States-is the subject of F. James Davis's 1991 book, Who is Black? One Nation's Definition. ${ }^{106}$

A number of books published during the last few years point to an increasingly sophisticated awareness of the multiplicity of specific African cultures that helped shape African-American and American life. The essays in Joseph Holloway's important edited volume, Africanisms in American Culture, Holloway and Vass's The African Heritage of American English, John Thornton's Africa and Africans in the Making of the Atlantic World, Salikoko Mufwene and Nancy Condon's Africanisms in AfroAmerican Language Variations, and many of the essays in Sterling Stuckey's Going through the Storm explore in all their specificity the distinct and differentiated African ethnic, linguistic, and religious traditions that shaped African-American and American life. ${ }^{107}$ Scholars' understanding of the complexities of African cultures and their relationship to African-American history and thought was also increased in the late 1980s and early 1990s by Kwame Anthony Appiah's In My Father's House: Africa in the Philosophy of Culture, V. Y. Mudimbe's The Invention of Africa and The Idea of Africa, and Bernard Makhosezwe Magubane's The Ties that Bind: African-American Consciousness of Africa. ${ }^{108}$

The 1990s also brought new attention to dimensions of black expressive culture previously neglected as subjects for serious study. Rap, for example, is examined by Houston Baker in Black Studies, Rap and the Academy; by Tricia Rose in Black Noise; and by Gregory Stephens in "Interracial Dialogue in Rap Music." 109 The politics of black hair is among the subjects that Kobena Mercer explores in his 1994 book, Welcome to the Jungle: New Positions in Black Cultural Studies, and the topic was addressed as well in 1994 by scholars including Tricia Rose, Elizabeth Alexander, Farrah Griffin, and Robin D. G. Kelley. ${ }^{110}$ Other innovative discussions of black expressive culture in the 1990s include Farrah Jasmine Griffin's “Who Set You Flowin?" The African-Amèrican Migration Narrative and Glen Alyn's I Say Me for a Parable: The Oral Autobiography of Mance Lipscomb, Texas Bluesman. ${ }^{111}$ Given the world- 
Autobiography of Mance Lipscomb, Texas Bluesman. ${ }^{11}$ Given the worldwide popularity among young people of rap, braids, and the blues, scholars' insights into these forms of African-American expressive culture may help elucidate the dynamics of international youth culture in the future.

For some scholars, the process of complicating "blackness" in the 1990s occasionally entailed being provocative and "impertinent." "What is black culture?” asked David L. Smith in 1994:

When Wynton Marsalis plays a Haydn concerto or Leontyne Price sings a Verdi opera, is that black culture? Similarly, when Dr. John plays the blues or Travis Tritt sings soul, is that black culture? In all these cases our answer is probably no. Yet black people relish a game invented by James Naismith, a white man. Don't we commonly accept basketball as part of black culture? ... Is participation in black culture a biological privilege, or can anybody join? Conversely, is black culture obligatory for black people, and does blackness preclude them from mastering non-black cultural modes? Such questions are impertinent, because in the absence of fundamental definitions, they cannot be answered.

Building on the "pragmatist spirit" articulated by Cornel West in The American Evasion of Philosophy, Smith argues that "we ought to abandon attempts to understand race and blackness in terms of foundations and definitional certainty. Instead, we should take our actual experience of race and blackness as our starting point." Acknowledging "openly the arbitrariness of racial categories will be an important, though not sufficient, step toward the demystification of America's exploitative racial culture." The challenge, Smith writes, "is to understand what race is, how it functions, and ultimately to theorize how we might endeavor within a culture bound by race to subvert the subordinating strictures that race was designed to perpetuate. ${ }^{113}$ Or, as West put it in 1993 ,

New World African modernity radically interrogates and creatively appropriates Euro-American modernity by examining how "race" and "Africa"themselves modern European constructs-yield insights and blindnesses, springboards and roadblocks for our understanding of multivarious and multileveled modernities. ${ }^{14}$ 


\section{Remapping American Culture ${ }^{115}$}

The American synthesis has an inevitable Anglo-Saxon coloration.

\section{-Arthur Schlesinger, The Disuniting of America}

The monolith is a myth; the "white man's land" even more mythical, and the multicultural nature of America is a fact from its very inception.

-Maghan Keita, "Multiculturalism"

"Staring at one another across the void of American identity," Kenneth Warren wrote in Black and White Strangers,

African and European Americans have been constructing themselves and each other, each side trying to lay claim to an unchallenged cultural legacy and each failing (to paraphrase Twain) to prove unambiguous title. As each side strives to construct a sui generis account of its own heritage, the Other insists upon emerging in unexpected and embarrassing places."116

Clearly, American culture always was, and continues to be, in Albert Murray's phrase, "incontestably mulatto." 117

But the "incontestably mulatto" nature of American culture continues to be resisted in some quarters. "The WASP character is the American character," trumpeted Richard Brookhiser in his 1991 book, The Way of the WASP. ${ }^{118}$ "The U.S. has always been an Anglo-Saxon civilization," declared Laurence Auster in his apocalyptic 1990 book, The Path of National Suicide: An Essay on Immigration and Multiculturalism. ${ }^{119}$ Auster and Brookhiser fail to understand that what they refer to as the white AngloSaxon Protestant civilization of the United States was itself shaped from the start by people and traditions who were not white, or Anglo-Saxon, or Protestant. American culture has always been multicultural, and, rather than some newfangled plot by "tenured radicals" as some have charged, the effort to move the stories we tell about who we are closer to the realities of who we are and who we have been is fueled more by a desire for truth and accuracy than it is fueled by any political agenda.

If we apply to our culture the "one drop" rule that in the United States has long classified anyone with one drop of black blood as black, then all of American culture is black. But well into the twentieth century, as James Horton notes, "white Americans continued to deny, yèt exhibit, the complexity of their cultural heritage." ${ }^{120}$ The racism and myopia that has allowed this denial to continue should be examined not just in black 
studies courses but throughout the curriculum. The influence of white figures and texts on African-American writers and thinkers should be examined throughout the curriculum as well. We need to formulate new ways of addressing such issues as influence, exchange, appropriation, "homage," intertextual dialogue, "signifying," "capping," borrowing, theft, synergy, and cross-fertilization. ${ }^{121}$ "Rather than mourning the loss of some putative ancestral purity," Henry Louis Gates, Jr., writes in Loose Canons: Notes on the Culture Wars, "we can recognize what's valuable, resilient, even cohesive in the hybrid and variegated nature of our modernity. . . For whatever the outcome of the culture wars in the academy the world we live in is multicultural already. Mixing and hybridity are the rule, not the exception." This is a fact that we can no longer bury or dismiss. It is by understanding and celebrating the hybridity of mainstream American culture, and acknowledging the multicultural tributaries that have fed that mainstream, that we can collectively forge what Gates refers to as "a new, and vital, common American culture in the twenty-first century." 122

We must learn to reclaim our complex roots while not ignoring the history of racism that allowed us, for over two hundred years, to ignore and deny who and what we really were all along. We must learn to appreciate the distinctive blend of cultural traditions that shaped us while simultaneously working to dismantle the paradigms that prevented (and continue to prevent) so many African Americans from receiving credit and respect for all they did (and do) to create that common culture known as "American" throughout the world.

We need to come to terms with how the racism that denied African Americans respect, rights, and agency for hundreds of years also deformed scholars' understanding of the dynamics of twentieth-century life and thought not only in the United States but throughout the world. How, for example, did Europeans as well as Americans disengage themselves from the nineteenth-century values of the Victorian era? Susan Curtis's 1994 cultural biography of Scott Joplin leaves the reader with the sense that any explanation that leaves out the effects of ragtime is of necessity partial and incomplete. ${ }^{123}$ And how has our understanding of "modernity" been hobbled by our failure to understand the transatlantic exchanges so lucidly explored in 1993 by Paul Gilroy? Modernity, like the musical transformations Gilroy tracks around the globe, is the product of "untidy elements in a story of hybridisation and intermixture that inevitably disappoints the desire for cultural and therefore racial purity, whatever its source."124

The first years of the last decade of the twentieth century may have 
brought the withering away of simplistic essentialist notions of racial identity as well as increasingly sophisticated understandings of how power relations built on antiquated, discredited assumptions of racial difference sustain and perpetuate themselves. As the twentieth century draws to a close, however, scholars may find their work increasingly at odds with the vision of America's past and present promoted by popular demagogues nostalgic for a time when the "whiteness" of American culture was assumed and when white privilege went unnamed, unexamined, unchallenged. In such an atmosphere, in which overt and coded racist policies are routinely sanctioned, and in which truth and justice are dismissed for political ends, scholars' efforts to revise the stories we tell about who we are to reflect what we have learned about where we have been are all the more important. We are now and have always been a culture in which a vast range of voices and traditions have constantly shaped each other in profound ways. Our teaching and our scholarship must take into account our increasingly complex understanding of what our common culture is and how it evolved. Doing so will force us to examine how an unequal distribution not of talent but of power allowed a patently false monocultural myth to mask and distort a multicultural reality. The new vision of our culture will be truer than any that we have had before-and more interesting. It will also be a healthier base on which to build our society's future. Forging such a vision may not be easy, but it is a challenge we should be eager to embrace.

\section{NOTES}

This essay (in expanded form) will appear in Criticism on the Color Line; Desegregating American Literary Studies, edited by Henry Wonham, (1996, Rutgers, the State University and is printed here with permission of Rutgers University Press. Portions of this essay were presented between September 1994 and April 1995 as the Butler Lecture sponsored by the Bertrand Library, Bucknell University; at a conference on "The Question of Race in the Americas" sponsored by the Women's Studies Program, University of Pennsylvania; as the keynote talk at a conference on "Multiculturalism in Modern America" sponsored by the USIS and the Turkish American Studies Association, in Çesme, Turkey; at the Annenberg School of Communications at the University of Pennsylvania; and as the Richardson Lecture sponsored by the American Studies Program of Georgetown University. I am grateful to scholars at all of these venues for their invaluable comments and criticisms. I also want to thank David Bradley, Emily Budick, Evan Carton, Robert Crunden, Joel Dinerstein, Michael Eric Dyson, Milton Fisher, Neil Foley, Skip Gates, Ted Gordon, Betti-Sue Hertz, Jim Horton, Kathleen 
Jamieson, Maghan Keita, George Lipsitz, Lucy Maddox, Liz Maguire, Jim Miller, Leslie Mitchner, Dana Nelson, Carla Peterson, Lillian Robinson, David Roediger, Arnold Rampersad, Jeffrey Rubin-Dorsky, David L. Smith, Danille Taylor-Guthrie, Karen Winkler, and Harry Wonham, for having shared their thoughts, their libraries, and their work-in-progress with me as generously as they did.

1. Ralph Ellison, "Change the Joke and Slip the Yoke" Partisan Review 25 (spring 1958): 212-22, reprinted in Ralph Ellison, Shadow and Act (New York, 1953), 55.

2. The push toward multicultural education in the 1980s and 1990s sparked increased awareness of the interactions and interpenetration of a number of cultural traditions in addition to African-American, Anglo-American, and Euro-American: Latino, Asian-American, and Native American, to name a few. I would not want my decision to frame this essay in "black" and "white" terms to be interpreted as a denial of the importance of these other groups and traditions in our efforts to reformulate and reconfigure our cultural narratives; I am simply choosing to focus, at this time, on one particular aspect of a complex set of issues. Indeed, perhaps the most apt term for describing the new perspectives on American identity that current research requires is Gloria Anzaldúa's concept of "mestiza consciousness," an idea that came from Anzaldúa's efforts to describe an identity that blended Anglo, Spanish, Mexican, and Indian cultures, languages, and gene pools. See Gloria Anzaldúa, Borderlands: La Frontera/The New Mestiza (San Francisco, 1987). My own thoughts about the construction of cultural narratives have been deeply influenced by Anzaldúa's work and by the numerous conversations we have had on the subject over the last six years. Indeed, my first public presentation of some of the ideas in this essay was in a paper entitled "America's Fear of her Mestisaje" that I delivered at a faculty colloquium (in which Anzaldúa also participated) at the Universidad Nacional Autónoma de México in Mexico City, June, 1992. My talk addressed, in part, the differences between a society like that of the U.S. that denied the "mestisaje" at its core, and a society like that of Mexico that made the idea of "mestisaje" central to its official cultural narratives.

3. Dean Flower, "Desegregating the Syllabus," Hudson Review (winter 1994): 68384.

4. Lee Katterman, "In Search of an 'American' Literature: UM Scholar Argues that Emphasis on the British Tradition Creates Damaging Myths," Research News 41 (Jan.Feb. 1990): 14-15. David Bradley described a similar phenomenon in "Black and American, 1982" Esquire (May 1982), reprinted in Essays for the '80s, ed. William Vesterman (New York, 1987), 397-413. Also of interest is the Modern Language Association survey released in December 1994, "What's Being Taught in Survey Courses?: Findings from a 1990-1991 MLA Survey of English Departments," which generated widespread media attention for its finding that, as the Los Angeles Times put it, "Dead white men are alive and well and being widely taught in college English courses." (Amy Wallace, "Defenders of Shakespeare Do Protest Too Much, Study Finds" Los Angeles Times, 29 Dec. 1994).

5. William A. Henry III, "Upside Down in the Groves of Academe" Time, 1 Apr. 1991, 66-69. The professor was Valerie Babb of Georgetown University.

6. Toni Morrison, Playing in the Dark: Whiteness and the Literary Imagination (Cambridge, Mass., 1992), 4-5, xii-xiii.

7. Eric Sundquist, To Wake the Nations: Race in the Making of American Literature (Cambridge, Mass., 1993), 7.

8. Ellison wrote, "The Negro looks at the white man and finds it difficult to believe that the 'grays' - a negro term for white people — can be so absurdly self-deluded over the true interrelatedness of blackness and whiteness." "Change the Joke," 212-22. 
Another critic who attended to the "interrelatedness of blackness and whiteness" early in the game was French scholar Viola Sachs, who asked questions in this vein in works including Le Blanc et le Noir Chez Melville et Faulkner (Paris, 1974); La Contre-Bible De Melville: Moby-Dick Déchiffre (Paris, 1975); The Game of Creation: The Primeval Unlettered Language of Moby-Dick; or, The Whale (Paris, 1982); and The Myth of America: Essays in the Structures of Literary Imagination (Paris, 1973). See also Viola Sachs, ed., L'Imaginaire-Melville: A French Point of View (Saint-Denis, France, 1992); Toni Morrison, "Unspeakable Things Unspoken: The Afro-American Presence in American Literature" Michigan Quarterly Review 28 (winter 1989): 1-34; Eric Sundquist, "Mark Twain and Homer Plessy" Representations 24 (fall 1988); Eric Sundquist, "Faulkner, Race, and the Forms of American Fiction," in Faulkner and Race: Faulkner and Yoknapatawpha, ed. Doreen Fowler and Ann J. Abadie (Jackson, Miss., 1987), 1-34; Eric Sundquist, ed., New Essays on Uncle Tom's Cabin (New York, 1986). Other early studies that reflect aspects of the kind of approach Morrison urges include Sterling Brown's The Negro in American Fiction (Port Washington, N.Y., 1937); Seymour Gross and John Edward Hardy's Images of the Negro in American Literature (Chicago, 1966); Jean Fagan Yellin's The Intricate Knot: Black Figures in American Literature, 1776-1863 (New York, 1972); Carolyn Karcher's Shadow over the Promised Land: Slavery, Race, and Violence in Melville's America (Baton Rouge, La., 1980); and Michael Rogin's Subversive Genealogies: The Politics and Art of Herman Melville (Berkeley, 1985). Werner Sollors's pioneering book Beyond Ethnicity: Consent and Descent in American Culture (New York, 1986), as well as his edited collection, The Invention of Ethnicity (New York, 1989), must also be credited with helping to place on the agenda of contemporary scholars an issue that implicitly informs the studies discussed throughout this essay: the "constructed" nature of race and identity.

9. Robert Stepto, "Sharing the Thunder: The Literary Exchanges of Harriet Beecher Stowe, Henry Bibb, and Frederick Douglass," in New Essays on Uncle Tom's Cabin, 135-54.

10. Russell Reising, The Unusable Past: Theory and the Study of American Literature (New York, 1986), 267, 271.

11. Aldon Lynn Nielson, Reading Race: White American Poets and Racial Discourse in the Twentieth Century (Athens, Ga., 1988); Deborah E. McDowell and Arnold Rampersad, ed., Slavery and the Literary Imagination (Baltimore, 1989).

12. Morrison, "Unspeakable Things Unspoken," 19.

13. Dana Nelson. The Word in Black and White: Reading "Race" in American Literature, 1638-1867 (New York, 1992).

14. Sterling Stuckey, "Follow Your Leader': The Theme of Cannibalism in Melville's 'Benito Cereno,'” in Going through the Storm: The Influence of African American Art in History (New York, 1994), 171-84; Eric Sundquist, "Melville, Delany, and New World Slavery," in To Wake the Nations, 135-221; Sachs, L'Imaginaire-Melville. Carolyn Karcher offered some preliminary examinations of the role of issues of race in Melville's work in her Shadow over the Promised Land: Slavery, Race, and Violence in Melville's America (Baton Rouge, La., 1980); as did Rogin in Subversive Genealogies.

15. Michael Berthold, "Moby-Dick and American Slave Narrative," The Massachusetts Review 35 (spring 1994): 135-48.

16. Werner Sollors, "Ethnicity," in Critical Terms for Literary Śtudy, ed. Frank Lentriccia and Thomas McLaughlin (Chicago, 1990), 288-305; Lawrence Howe, "Transcending the Limits of Experience: Mark Twain's Life on the Mississippi," American Literature 63 (Sept. 1991): 420-39. 
17. Kenneth W. Warren, Black and White Strangers: Race and American Literary Realism (Chicago, 1993), 9, 10, 31, 15.

18. See Robert F. Fleissner, T. S. Eliot and the Heritage of Africa (New York, 1992) and David Chinitz, "T. S. Eliot and the Cultural Divide," PMLA, 110 (Mar. 1995): 236-47, particularly 244-46.

19. Michael North, The Dialect of Modernism: Race, Language and TwentiethCentury Literature (New York, 1994), 3.

20. Ibid., 81.

21. Aldon L. Nielson, Writing between the Lines: Race and Intertextuality (Athens, Ga., 1994).

22. For discussions of Vachel Lindsay, T. S. Eliot, and Wallace Stevens, see Rachel Blau DuPlessis, “'HOO, HOO, HOO': Some Episodes in the Construction of Modern Whiteness," American Literature 67 (Dec. 1995). For discussions of Wallace Stevens, Marianne Moore, William Carlos Williams, Mina Loy, Gertrude Stein, and Ezra Pound, see DuPlessis, “'Darken Your Speech': Racialized Cultural Work in Stevens, Moore, Williams, Loy, Stein and Pound," in An Area of Act: Race and American Poetries and Poetics, ed Aldon L. Nielsen (Urbana, Ill., 1995). See also Charles Bernstein, "Professing Stein/Stein Professing," Poetics Journal 9 (1991): 44-50.

23. Doyle also examines treatment of the "race mother" figure by black novelists including Jean Toomer, Ralph Ellison, and Toni Morrison. Laura Doyle, Bordering on the Body: The Race Mother in Modern Fiction (New York, 1994).

24. Carla Peterson. "The Remaking of Americans: Gertrude Stein and AfricanAmerican Musical Traditions," in Criticism on the Color Line, ed. Henry Wonham (New Brunswick, N.J., 1996).

25. Joe Adamson, Bugs Bunny: Fifty Years and Only One Grey Hare (New York, 1990); David Roediger, "A Long Journey to the Hip Hop Nation," St. Louis PostDispatch, 18 Mar. 1994.

26. Ibid.

27. Howard I. Sacks and Judith Rose Sacks, Way up North in Dixie: A Black Family's Claim to the Confederate Anthem (Washington, D.C., 1993).

28. Eric Lott, Love and Theft: Blackface Minstrelsy and the American Working Class (New York, 1993), 3-4. Some similarly complex approaches to the minstrel show in American popular culture emerge in Saidya Hartman's book Performing Blackness (forthcoming). Among the many interesting offshoots of Lott's central discussion is his suggestion that many chapters of "white" cultural history usually written without reference to race-such as the history of cultural styles among whites known generally as "bohemianism"-must take into account an ever-present racial subtext. (Lott, Love and Theft, 50-51).

29. David R. Roediger, The Wages of Whiteness: Race and the Making of the American Working Class (New York, 1991); David R. Roediger, Towards the Abolition of Whiteness (New York, 1994).

30. Roediger, Towards the Abolition of Whiteness, 12, ix, 75. Roediger provides a useful overview of labor historians' responses to the issue of race in chapter 6, "The Crisis in Labor History: Race, Gender and the Replotting of the Working Class Past in the United States," 69-81. Roediger notes that "the recent outpouring of work on African American, Asian American and Latino labor history further signals the possibility that a consideration of race will structure, and not just appear episodically in, new attempts at synthesis in US working class history" (75). Some of the works Roediger credits with moving the field in this direction that appeared in the early 1990s are: Rick Halpern, "Race, Ethnicity and the Union in the Chicago Stockyards, 19171922," International Review of Social History 37 (Jan. 1992); Iver Bernstein, The New 
York City Draft Riots: Their Significance for American Society and Politics in the Age of the Civil War (New York, 1990); Eric Arnesen, Waterfront Workers of New Orleans, Race, Class and Politics (New York, 1990); Eric Arnesen, "Rethinking the Historical Relationship between Black Workers and the Labor Movement," Radical History Review (winter 1993); Wayne Durrill, War of Another Kind: A Southern Community in the Great Rebellion (New York, 1990); Nancy Quann Wickham, "Who Controls the Hiring Hall? The Struggle for Job Control in the ILWU during World War II"; and Bruce Nelson, "Class and Race in the Crescent City: The ILWU from San Francisco to New Orleans," both in Steven Russwurm, ed., The CIO's Left-Led Unions (New Brunswick, N.J., 1992); Robert Zieger, ed., Organized Labor in the Twentieth Century South (Knoxville, Tenn., 1991); Earl Lewis, In Their Own Interest: Race, Class and Power in Twentieth-Century Norfolk, Virginia (Berkeley, 1991); Joe William Trotter, Coal, Class and Color: Blacks in Southern West Virginia, 1915-32 (1990); Robin D. G. Kelley, Hammer and Hoe: Alabama Communists during the Great Depression (Chapel Hill, N.C., 1990) and "We Are Not What We Seem': Rethinking Black Working-Class Oppostion in the Jim Crow South" Journal of American History 80 (June 1993): 75-113; Robin Asher and Charles Stephenson, ed., Labor Divided: Race and Ethnicity in United States Labor Struggles (Albany, N.Y., 1990).

31. Sander Gilman, "The Jewish Nose: Are Jews White? Or, The History of the Nose Job" in Gilman, The Jew's Body (New York, 1991), 172.

32. Gilman, Jew's Body, 204, 174. Gilman is quoting Robert Knox's The Races of Men: A Fragment (Philadelphia, 1850), 134.

33. Gilman, Jew's Body, 174, 238.

34. Michael Rogin, "Blackface, White Noise: The Jewish Jazz Singer Finds his Voice," Critical Inquiry 18 (spring 1992): 417-53; 421. See also Rogin, “'Democracy and Burnt Cork': The End of Blackface, the Beginning of Civil Rights," Representations 46 (spring 1994): 1-34; and Rogin, "Making America Home: Racial Masquerade and Ethnic Assimilation in the Transition to Talking Pictures," Journal of American History 79 (Dec. 1992): 1050-77.

35. In Steven Gregory and Roger Sanjek, ed., Race (New Brunswick, N.J., 1994).

36. Alexander Saxton, The Rise and Fall of the White Republic: Class, Politics and Mass Culture in Nineteenth-Century America (New York, 1991).

37. Melville J. Herskovits, The Myth of the Negro Past (Boston, 1958); Peter Wood, Black Majority: Negroes in Colonial South Carolina from 1670 through the Stono Rebellion (New York, 1974). Sidney Kaplan, American Studies in Black and White: Selected Essays, 1949-1989, ed. Allan D. Austin (Amherst, Mass., 1991). See also Mechal Sobel, The World They Made Together: Black and White Values in EighteenthCentury Virginia (Princeton, 1987).

38. The publication in 1991 of Kaplan's collected essays is further testimony to the renewed interest in this kind of research. See Kaplan, American Studies in Black and White.

39. John Edward Philips, "The African Heritage of White America," in Africanisms in American Culture, ed. Joseph E. Holloway (Bloomington, Ind., 1990), 225-39, 226. The only articles from an earlier era that Philips recognizes as directly addressing this issue are Melville Herskovits' 1935 essay, "What Has Africa Given America?" and John A. Davis's 1964 article, "The Influence of Africans on American Culture." Summarizing the key points of these early forays into the subject, Philips notes that Herskovits mentioned areas of cultural influence including music (spirituals and jazz), speech (southern dialect), Southern etiquette, cuisine and religious behavior (229). John A. Davis mentioned "the formal politeness and courtesy of the South" in passing but "like most investigators he was concerned primarily with the influence of Africa on blacks" (229). 
40. C. Vann Woodward, "Clio with Soul," Journal of American History 1 (June 1969): 17.

41. Philips, "African Heritage of White America," 230, 236, 237.

42. William D. Piersen, Black Legacy: America's Hidden Heritage (Amherst, Mass., 1993), xv. Portions of my discussion of Piersen's book first appeared in my review of the book in American Literature (Sept. 1994): 616-17.

43. Gwendolyn Midlo Hall, Africans in Colonial Louisiana (Baton Rouge, La., 1992).

44. Roger Abrahams, Singing the Master: The Emergence of African-American Culture in the Plantation South (New York, 1992), xvii.

45. W. J. Cash, The Mind of the South (New York, 1963), ix.

46. Abrahams, Singing the Master, xxiii.

47. Ibid., 131-32. As Abrahams reminds us, it was Constance Rourke who first pointed out the central place of minstrelsy in American popular culture. See Rourke, American Humor: A Study of National Character (New York, 1931).

48. David Roediger, "Guineas, Wiggers, and the Dramas of Racialized Culture," forthcoming in American Literary History, 1995.

49. Ibid. Roediger cites Ellison, Going to the Territory (New York, 1987), 21; and A. Sivanandan, "Challenging Racism," in Communities of Resistance: Writings on Black Struggles for Socialism (London, 1990), 66.

50. Roediger, "Guineas, Wiggers and the Dramas of Racialized Culture," 10.

51. Ibid., 11.

52. Ibid., 14.

53. Ibid., 16. Interestingly, Mark Twain's earliest exposure to a scathing satirical critique of white society also came from a black performer, the slave named "Jerry" whom Twain called "the greatest orator in the United States" in his essay, "Corn-Pone Opinions." See Shelley Fisher Fishkin, Was Huck Black? Mark Twain and AfricanAmerican Voices (New York, 1993), 53-76.

54. Roediger, "Long Journey."

55. Ibid.

56. Josef Jarab, "Black Stars, Red Star, and the Blues," in The Black Columbiad: Defining Moments in African-American Literature and Culture, ed. Werner Sollors and Maria Diedrich (Cambridge, Mass., 1994), 167-73.

57. Kemp-Rotan's research (a forthcoming book) is described in Mary Ann French's article, "A Hurting on the Soul," The Washington Post, 17 Nov. 1944, Home Section, 14.

58. Paul Gilroy, The Black Atlantic: Modernity and Double Consciousness (Cambridge, 1993), 4.

59. Mel Watkins, On the Real Side: Laughing, Lying and Signifying-the Underground Tradition of African-American Humor that Transformed American Culture from Slavery to Richard Pryor (New York, 1994). The complex racial exchange involved in the of the humor of the Amos ' $n$ ' Andy show, a topic that Watkins raises, was examined by other scholars in the 1990s as well. See Melvin Patrick Ely's The Adventures of Amos ' $n$ ' Andy: A Social History of an American Phenomenon (New York, 1991); and George Lipsitz's Time Passages: Collective Memory and American Popular Culture (Minneapolis, 1994), 39-75.

60. Watkins, On the Real Side, 396, 485-86.

61. J. L. Dillard, "The Development of Southern," in A History of American English (New York, 1992), 93-114, 96, 101.

62. Joseph Holloway and Winifred Vass, The African Heritage of American English (Bloomington, Ind., 1993), xiii.

63. Ibid., 137. 
64. Wayne A. Glowka and Donald M. Lance, ed., Language Variation in North American English: Research and Teaching (New York, 1993), 14.

65. Walt Wolfram, "Teaching the Grammar of Vernacular English," in Glowka and Lance, Language Variation, 27.

66. Kathleen Hall Jamieson, Dirty Politics: Deception, Distraction, and Democracy (New York, 1992).

67. Celeste Michelle Condit and John Louis Lucaites, Crafting Equality: America's Anglo-African Word (Chicago, 1993), xviii.

68. Eli Leon's Models in the Mind: African Prototypes in American Patchwork was the exhibition catalog for an exhibit at the Diggs Gallery at Winston-Salem State University, Winston-Salem, N.C., in 1992.

69. Guy C. McElroy, Facing History: The Black Image in American Art, 1710-1940 (San Franciso, 1990); Albert Boime, The Art of Exclusion: Representing Blacks in the Nineteenth Century (Washington, D.C., 1990); and Kaplan, American Studies in Black and White. The recent volumes built, of course, on Hugh Honour's magisterial fourvolume study, The Image of the Black in Western Art (New York, 1976).

70. Jan Nederveen Pieterse's White on Black: Images of Africa and Blacks in Western Popular Culture (New Haven, 1992).

71. "The Perverse Double: Or, a Cure for the Discourse of Whiteness," exhibition curated by Todd Ayoung. 9 January-27 February 1992, Longwood Arts Gallery, Bronx, New York.

72. Brenda Dixon-Gottschild, "Stripping the Emperor: Africanisms in American Concert Dance," paper presented at the American Studies Association, October 1994, Nashville, Tenn. A version of this paper will appear in the forthcoming volume, Looking Out: Perspectives on Dance and Criticism in a Multicultural World, ed. David Gere, Lewis Segal, Patrice Koelsch, and Elizabeh Zimmer. See also John Szwed and Morton Marks, "The Afro-American Transformation of European Set Dances and Dance Suites." Dance Research Journal 20 (summer 1988): 29-36.

73. Theodore W. Allen, The Invention of the White Race, volume 1, Racial Oppression and Social Control (New York, 1994).

74. Neil Foley, "'Almost White': Mexican Tenant Farmers and the Politics of Race in Socialist Central Texas, 1911-1917," unpublished paper presented at the Southern Historical Association, Louisville, Ky., November 1994.

75. Jane Marcus, "Bonding and Bondage: Nancy Cunard and the Making of the Negro Anthology," in Border, Boundaries and Frames: Cultural Criticism and Cultural Studies, ed. Mae Henderson (New York, 1994), 44-45.

76. Vron Ware, Beyond the Pale: White Women, Racism and History (New York, 1994).

77. Ruth Frankenberg, "Whiteness and Americanness: Explaining Constructions of Race, Culture and Nation in White Women's Life Narratives," in Gregory and Sanjek, Race, 62-77. See also Ruth Frankenberg, White Women, Race Matters: The Social Construction of Whiteness (Minneapolis, 1993).

78. Frankenberg, "Whiteness and Americanness," 66, 74.

79. bell hooks, Black Looks: Race and Representation (Boston, 1992), 12.

80. "Editorial: Abolish the White Race-By Any Means Necessary," Race Traitor 1 (winter 1993), 1-2.

81. Signs that this practice is eroding in the 1990s include the publication of such groundbreaking volumes as the Heath Anthology of American Literature, ed. Paul Lauter (Lexington, Mass., 1990), and its widespread adoption in courses; and The Columbia History of the American Novel, ed. Emory Eliot (New York, 1991). Both of these texts pioneered in remapping the terrain we call "American literature." Critical 
studies that resist the notion of segregated canons by exploring parallel issues in works by black and white writers include Werner Sollors's early and innovative Beyond Ethnicity: Consent and Descent in American Culture (New York, 1986); Peter Messent's New Readings in the American Novel (New York, 1990); Elizabeth Ammons's Conflicting Stories: American Women Writers at the Turn into the Twentieth Century (New York, 1992); Alessandro Portelli's Il Testo E La Voce: Oralita, Letteratura, E Democrazia in America (Rome, 1992; trans. The Text and the Voice: Writing, Speaking, and Democracy in American Literature [New York, 1995]); and Sundquist's To Wake the Nations.

82. Elliott Butler-Evans examined some related issues in "Beyond Essentialism: Rethinking Afro-American Cultural Theory," in Inscriptions 5: Traveling Theories; Traveling Theorists, ed. James Clifford and Vivek Dhareshwar (1995), 121-35.

83. Henry Louis Gates, Jr., "Criticism in the Jungle," in Black Literature and Literary Theory, ed. Henry Louis Gates, Jr. (New York, 1984), 4.

84. Ann DuCille, The Coupling Convention: Sex, Text, and Tradition in Black Women's Fiction (New York, 1993).

85. Richard Wright, Savage Holiday, intro. Gerald Early (1958; Jackson, Miss., 1994).

86. Carla Peterson, Doers of the Word: African-American Women Writers and Speakers in the North, 1830-1880 (New York, 1995); Claudia Tate, Domestic Allegories of Political Desire: The Black Heroine's Text at the Turn of the Century (New York, 1992); Frances Smith Foster, Written by Herself: Literary Production by African American Women, 1746-1892 (Bloomington, Ind., 1993); Thadious Davis, Nella Larsen: Novelist of the Harlem Renaissance: A Woman's Life Unveiled (Baton Rouge, La., 1994); Melba Joyce Boyd, Discarded Legacy: Politics and Poetics in the Life of Frances E. W. Harper, 1825-1911 (Detroit, 1994); Dickson D. Bruce, Jr. Archibald Grimké: Portrait of a Black Independent (Baton Rouge, La., 1994).

87. Adelaide Cromwell, The Other Brahmins: Boston's Black Upper Class, 1850 1950 (Fayetteville, Ark., 1994); Willard B. Gatewood, Aristocrats of Color: The Black Elite, 1880-1920 (Bloomington, Ind., 1990); J. Clay Smith, Jr., Emancipation: The Making of the Black Lawyer, 1844-1944 (Philadelphia, 1993); Charles Thomas, Black and Blue: Profiles of Blacks in IBM (Atlanta, 1993); James Joy and Ruth Farmer, ed. Spirit, Space and Survival: African American Women in White Academe (New York, 1993); Ellis Cose, The Rage of a Privileged Class (New York, 1993); Sara LawrenceLightfoot, I've Known Rivers: Lives of Loss and Liberation (Reading, Mass., 1994). See also Ann Morris and Henrietta Ambrose, North Webster: A Photographic History of a Black Community (Bloomington, Ind., 1993); Charles T. Banner-Halley, The Fruits of Integration: Black Middle-Class Ideology and Culture, 1960-1990 (Jackson, Miss., 1990); and Carla L. Peterson, “'Further Liftings of the Veil': Gender, Class, and Labor in Frances E. W. Harper's Iola Leroy," in Listening to Silences: New Essays in Feminist Criticism, ed. Elaine Hedges and Shelley Fisher Fishkin (New York, 1994).

88. Ellis, "The New Black Aesthetic," 233-43.

89. Ibid., 241.

90. Ibid., 235.

91. William Johnson's Natchez: The Ante-bellum Diary of a Free Negro, ed. William Ransom Hogan and Edwin Adams Davis, with a new introduction by William L. Andrews (Baton Rouge, La., 1993); Adele Logan Alexander, Ambiguous Lives: Free Women of Color in Rural Georgia, 1789-1879 (Fayetteville, Ark., 1991).

92. James O. Horton, Free People of Color: Inside the African American Community (Washington, D.C., 1993), 14. Horton partly endorses Clarence Walker's provocative call-in Deromanticizing Black History: Critical Essays and Reappraisals (Knoxville, 
Tenn., 1991)—that scholars not paper over or ignore divisions, disunity, and tensions in black communities over time.

93. See David Steven Cohen, "Afro-Dutch Folklore and Folklife," in Cohen, Folk Legacies Revisited (New Brunswick, N.J., 1995), 31-45; Allison Blakely, Blacks in the Dutch World: The Evolution of Racial Imagery in a Modern Society (Bloomington Ind., 1993); Laurence Mordekhai Thomas, "The Soul of Identity: Jews and Blacks," in Wrestling with the Angel: Jewish Identity in the Academy, ed. Jeffrey Rubin-Dorsky and Shelley Fisher Fishkin (Madison, Wisc., 1996); Oliver W. Holmes, "Perceptions of 'Otherness': Isaac de Pinto, Voltaire, and a Personal Interpretation of Jewish Experience," in Wrestling with the Angel. See also Laurence Mordekhai Thomas,Vessels of Evil: American Slavery and the Holocaust (Philadelphia, 1993).

94. Michel Fabre, Richard Wright: Books and Writers (Jackson, Miss., 1990).

95. See Fishkin, Was Huck Black? For further comments on Mark Twain by Bradley and Morrison, see David Bradley, preface to How to Tell a Story and Other Essays; and Toni Morrison, preface to Adventures of Huckleberry Finn, in The Oxford Mark Twain, ed. Shelley Fisher Fishkin, 29 vols. (New York, 1996).

96. David Bradley, "Our Crowd, Their Crowd, and Moby-Dick" in The Evermoving Dawn: Essays in Celebration of the Melville Centennial, ed. John Bryant and Robert Milder (Kent, Ohio, 1996).

97. David Levering Lewis, W. E. B. Du Bois: Biography of a Race, 1868-1919 (New York, 1993). Lewis's access to Du Bois's papers allowed him to extend and amplify a number of issues first raised in Arnold Rampersad's early groundbreaking study, The Art and Imagination of W. E. B. Du Bois (New York, 1976).

98. Richard Yarborough, "Strategies of Characterization in Uncle Tom's Cabin and the Early Afro-American Novel," in Sundquist, New Essays on Uncle Tom's Cabin.

99. DuCille, Coupling Convention, 24.

100. Philip M. Richards, "Phillis Wheatley and Literary Americanization," American Quarterly 44 (June 1992): 163-91; Carla Peterson, Doers of the Word; and DuCille, Coupling Convention.

101. Ann Douglas, Terrible Honesty: Mongrel Manhattan in the 1920s (New York, 1995), 82. See also Tracy Mishkin, ed., Literary Influence and African-American Writers (New York, 1995).

102. Michael Eric Dyson, "Language, Race and Identity," unpublished paper presented at "The Power of Language," Mark Twain Memorial Fall Symposium, October 1994, Hartford, Conn. In a related vein, see Todd Vogel, “The Master's Tools Revisited: Foundation Work in Anna Julia Cooper," in Wonham, Criticism on the Color Line.

103. Dyson, "Language, Race and Identity," 5.

104. Michael Eric Dyson, Reflecting Black: African-American Cultural Criticism (Minneapolis, Minn., 1993), 162-63.

105. Adrian Piper, "Passing for White, Passing for Black" Transition 58 (summer 1990), 14-32; Maureen T. Reddy, Crossing the Color Line: Race, Parenting and Culture (New Brunswick, N.J., 1994); Lise Funderburg, Black, White, Other: Biracial Americans Talk about Race and Identity (New York, 1994); Naomi Zack, Race and Mixed Race (Philadelphia, 1994); Shirlee Taylor Haizlip, The Sweeter the Juice: A Family Memoir in Black and White (New York, 1994); Gerald Early, ed., Lure and Loathing: Essays on Race, Identity, and the Ambivalence of Assimilation (New York, 1994).

106. F. James Davis, Who is Black? One Nation's Definition (University Park, Penn., 1991). 
107. Joseph Holloway, ed., Africanisms in American Culture (Bloomington, Ind., 1990); Joseph Holloway and Winifred K. Vass, The African Heritage of American English (Bloomington, Ind., 1993); John Thornton, Africa and Africans in the Making of the Atlantic World, 1400-1680 (Cambridge, Mass., 1992); Salikoko S. Mufwene and Nancy Condon, ed., Africanisms in Afro-American Language Variations (Athens, Ga., 1993); Stuckey, Going through the Storm.

108. Kwame Anthony Appiah, In My Father's House: Africa in the Philosophy of Culture (New York, 1992); V. Y. Mudimbe, The Invention of Africa (Bloomington, Ind., 1988); V. Y. Mudimbe, The Idea of Africa (Bloomington, Ind., 1994); Bernard Makhosezwe Magubane, The Ties that Bind: African-American Consciousness of Africa (Trenton, N.J., 1987).

109. Houston Baker, Black Studies, Rap and the Academy (Chicago, 1993); Tricia Rose, Black Noise (Hanover, N.H., 1994); Gregory Stephens, "Interracial Dialogue in Rap Music: Call-and-Response in a Multicultural Style," New Formation 16 (spring 192): 62-79.

110. Kobena Mercer, Welcome to the Jungle: New Positions in Black Cultural Studies (New York, 1994); Tricia Rose, Elizabeth Alexander, Farrah Griffin, and Robin D. G. Kelley all participated in the lively roundtable discussion, " Hairpiece'-The Culture and Politics of Black Hair," at the American Studies Association in Nashville, October 1994.

111. Farrah Jasmine Griffin, "Who Set You Flowin?" The African-American Migration Narrative (New York, 1995); Glen Alyn, I Say Me for a Parable: The Oral Autobiography of Mance Lipscomb, Texas Bluesman, As Told to and Compiled by Glen Alyn (New York, 1993).

112. David Lionel Smith, "What is Black Culture?," unpublished paper presented at Princeton University Conference on "Race Matters: Black Americans/U.S. Terrain," April 1994 (forthcoming in The House that Race Built: Black Americans, U.S. Terrain, ed. Wanneema Lublano [New York]).

113. Ibid. See also Cornel West, The American Evasion of Philosophy. (Madision, Wisc., 1989), 213.

114. Cornel West, Keeping Faith: Philosophy and Race in America. (New York, 1993), xii.

115. For further discussion of these ideas, see Shelley Fisher Fishkin, "The Multiculturalism of "Traditional' Culture," The Chronicle of Higher Education, 10 Mar. 1995, A48.

116. Kenneth Warren, Black and White Strangers, 10.

117. Albert Murray, The Omni-Americans (New York, 1983), 22.

118. Richard Brookhiser quoted in Stanley Fish, There's No Such Thing as Free Speech . . . and It's a Good Thing Too (New York, 1994), 84.

119. Laurence Auster quoted in Fish, There's No Such Thing as Free Speech, 83-84.

120. James O. Horton, "Race, Nationality and Cultural Identity: Free Blacks in the Age of Jackson," unpublished paper presented at the Organization of American Historians, Atlanta, Ga., April 1994.

121. Ann duCille's recent critique of Afrocentrism makes a related point: "While the empowering premise of an 'unembarassingly black' Afrocentric methodology offers an essential challenge to the assumed universality of European paradigms, it does not, to my mind, sufficiently address the question of cultural mediation that is the consequence of centuries of appropriation and cross-fertilization. Although it acknowledges blacks in the Americas as an Africa-derived people with a cultural legacy different from that of Euro-Americans, it does not adequately consider the degree to which that culture is 
necessarily intertwined with others around it." duCille, "Postcolonialism and Afrocentricity: Discourse and Dat Course," in The Black Columbiad: Defining Moments in African American Literature and Culture, ed. Werner Sollors and Maria Diedrich (Cambridge, Mass., 1994).

122. Henry Louis Gates, Jr., Loose Canons: Notes on the Culture Wars (New York, 1992), xvi.

123. Susan Curtis, Dancing to a Black Man's Tune: A Life of Scott Joplin (Columbia, Mo., 1994). See especially chap. 6, "The Legacy of Scott Joplin," 161-89.

124. Gilroy, Black Atlantic, 199. 